\title{
Airway regulatory $T$ cells are decreased in COPD with a rapid decline in lung function
}

Jonas Eriksson Ström ${ }^{1 *} \mathbb{D}$, Jamshid Pourazar ${ }^{1}$, Robert Linder ${ }^{1}$, Anders Blomberg ${ }^{1}$, Anne Lindberg ${ }^{1}$, Anders Bucht ${ }^{1,2}$ and Annelie F. Behndig ${ }^{1}$

\begin{abstract}
Background: Differences in the expression of regulatory T cells (Tregs) have been suggested to explain why some smokers develop COPD and some do not. Upregulation of Tregs in response to smoking would restrain airway inflammation and thus the development of COPD; while the absense of such upregulation would over time lead to chronic inflammation and COPD. We hypothesized that-among COPD patients—-the same mechanism would affect rate of decline in lung function; specifically, that a decreased expression of Tregs would be associated with a more rapid decline in $\mathrm{FEV}_{1}$.

Methods: Bronchoscopy with BAL was performed in 52 subjects recruited from the longitudinal OLIN COPD study; 12 with COPD and a rapid decline in lung function (loss of $\mathrm{FEV}_{1} \geq 60 \mathrm{ml} /$ year), 10 with COPD and a non-rapid decline in lung function (loss of FEV $1 \leq 30 \mathrm{ml} /$ year), 15 current and ex-smokers and 15 non-smokers with normal lung function. BAL lymphocyte subsets were determined using flow cytometry.
\end{abstract}

Results: The proportions of Tregs with regulatory function (FoxP3 ${ }^{+} / \mathrm{CD} 4^{+} \mathrm{CD} 25^{\text {bright }}$ ) were significantly lower in COPD subjects with a rapid decline in lung function compared to those with a non-rapid decline $(p=0.019)$. This result was confirmed in a mixed model regression analysis in which adjustments for inhaled corticosteroid usage, smoking, sex and age were evaluated. No significant difference was found between COPD subjects and smokers or non-smokers with normal lung function.

Conclusions: COPD subjects with a rapid decline in lung function had lower proportions of T cells with regulatory function in BAL fluid, suggesting that an inability to suppress the inflammatory response following smoking might lead to a more rapid decline in $\mathrm{FEV}_{1}$.

Trial registration Clinicaltrials.gov identifier NCT02729220

Keywords: Chronic obstructive pulmonary disease, Disease mechanisms, Lung function decline, Smoking habits, Bronchoalveolar lavage, Regulatory T cells

\section{Background}

Despite many efforts to understand the pathophysiology of COPD, it is still unknown why some long-term smokers develop COPD and some do not. One proposed explanation is differences in the ability to regulate the

*Correspondence: jonas.eriksson.strom@umu.se

${ }^{1}$ Department of Public Health and Clinical Medicine, Division of Medicine, Umeå University, 90187 Umeå, Sweden

Full list of author information is available at the end of the article immunological response to inhalation of tobacco smoke [1]. Upregulation of regulatory immune cells would restrain airway inflammation and, thus, the development of COPD; while the absence of such upregulation would over time lead to chronic inflammation and eventually COPD.

In COPD, airway inflammation is characterized by increased numbers of neutrophils and macrophages [2]. Macrophages are thought to play a major role as they can release matrix metalloproteinases capable of degrading original author(s) and the source, provide a link to the Creative Commons licence, and indicate if changes were made. The images or other third party material in this article are included in the article's Creative Commons licence, unless indicated otherwise in a credit line to the material. If material is not included in the article's Creative Commons licence and your intended use is not permitted by statutory regulation or exceeds the permitted use, you will need to obtain permission directly from the copyright holder. To view a copy of this licence, visit http://creativecommons.org/licenses/by/4.0/. The Creative Commons Public Domain Dedication waiver (http://creativeco mmons.org/publicdomain/zero/1.0/) applies to the data made available in this article, unless otherwise stated in a credit line to the data. 
the extracellular matrix in the lungs, as well as secrete chemokines that attract other immune cells such as monocytes and lymphocytes. In the latter population, the balance in COPD airways is tipped towards cytotoxic cell types such as $\mathrm{CD} 8^{+} \mathrm{T}$ cells [3] and NK cells [4]. Among regulatory immune cells, regulatory $\mathrm{T}$ cells (Tregs) are thought to be a key player, particularly in protecting the body from an over activated immune response [5].

Because of the chronic inflammation observed in COPD, it has been hypothesized that Tregs would be reduced in subjects affected by the disease [5]. In 2008, Barceló et al. showed that smokers with preserved lung function (LF) had a prominent upregulation of Tregs in bronchoalveolar lavage (BAL) compared to COPD subjects [1]. In other studies, however, Tregs have been found to be associated with pack-years rather than COPD status [6] and even to be increased in COPD [7].

In flow cytometry, the most commonly used marker for Tregs has been the intracellular FoxP3 (Forkhead Box P3) transcription factor, but early studies often defined Tregs as $\mathrm{CD} 4^{+} \mathrm{CD} 25^{\text {bright }}$ cells and some later studies instead opted for $\mathrm{CD} 127^{\text {low }}$ as the defining characteristic. While intended to identify the same cell population, these definitions do not overlap completely and might even reflect different immunological functions. For example, RoosEngstrand et al. showed that while CD $4^{+} \mathrm{CD} 25^{\text {bright }}$ cells were increased in smokers and COPD, the expression of FoxP3 was not, indicating an expansion of helper T cells without regulatory function in the studied population [8].

The current study is part of the KOLIN ('Respiratory and Cardiovascular Effects in COPD') project which was designed primarily to investigate the rapid decline phenotype of COPD. Focusing on regulatory immune cells, the aim was to assess the distribution of Tregs in COPD in general and its association with disease status, smoking status and rapid/non-rapid decline in LF in particular. Findings related to cytotoxic immune cells have been reported previously [4].

\section{Methods}

\section{Study subjects}

52 subjects participated in this cross-sectional study; 12 COPD subjects with a rapid decline in LF (COPD rapid), 10 COPD subjects with a non-rapid decline in LF (COPD non-rapid), 15 current and ex-smokers with normal LF (ever-smokers) and 15 non-smokers with normal LF (non-smokers).

All subjects were recruited from the OLIN COPD study [9] which also provided the longitudinal data used to calculate rate of decline in LF. Rapid decline was defined as a loss of forced expiratory volume in one second $\left(\mathrm{FEV}_{1}\right) \geq 60 \mathrm{ml} /$ year and non-rapid decline as a loss $\leq 30 \mathrm{ml} /$ year, both measured over at least 5 years.
The rate of decline was calculated as $\left(\mathrm{FEV}_{1}\right.$ at recruitment - $\mathrm{FEV}_{1}$ at follow-up)/number of years of follow-up [10].

To define COPD, the Global Initiative for Obstructive Lung Disease (GOLD) spirometric criteria were used [11]. All COPD subjects and Ever-smokers had a smoking history of at least 10 pack-years. Ex-smokers had stopped smoking at least 12 months prior to inclusion in the study. The recruitment process has been described in detail previously [10].

All subjects underwent bronchoscopy with BAL. Subjects with medical conditions contradicting bronchoscopy and/or inflammatory conditions or medication expected to affect the outcome of the study were excluded from participation. None of the subjects reported exacerbations in the 4 weeks prior to bronchoscopy.

Subject demographics and basic characteristics for COPD subjects are given in Table 1.

\section{Study design}

As all studies part of the KOLIN project, the current study was divided into three parts, each testing a different hypothesis (Fig. 1).

In part 1 the distribution of Treg populations was examined using as big groups as possible. All COPD subjects were compared to ever-smokers and

\begin{tabular}{|c|c|c|}
\hline & $\begin{array}{l}\text { COPD rapid } \\
\text { decline in LF } \\
n=12\end{array}$ & $\begin{array}{l}\text { COPD non- } \\
\text { rapid decline } \\
\text { in LF } \\
n=10\end{array}$ \\
\hline Female:Male & $2: 10$ & $4: 6$ \\
\hline Age $^{\mathrm{b}}$ & $63 \pm 7$ & $67 \pm 6$ \\
\hline$B M l^{\mathrm{a}}$ & $26 \pm 3$ & $25 \pm 3$ \\
\hline Current:Ex-smokers ${ }^{\mathrm{a}}$ & $8: 4$ & $3: 7$ \\
\hline Pack-years $^{\mathrm{a}}$ & $37.5 \pm 16$ & $33 \pm 11$ \\
\hline $\mathrm{FEV}_{1}$, percent of predicted ${ }^{\mathrm{b}}$ & $60 \pm 15$ & $63 \pm 19$ \\
\hline $\mathrm{FEV}_{1} N \mathrm{NC}^{\mathrm{b}}$ & $0.52 \pm 0.12$ & $0.54 \pm 0.11$ \\
\hline BAL-recovery, $\%^{c}$ & $44 \pm 16$ & $40 \pm 19$ \\
\hline Annual decline in $\mathrm{FEV}_{1}, \mathrm{ml}^{\mathrm{b}}$ & $86 \pm 29$ & $16 \pm 17$ \\
\hline Use of inhaled corticosteroids; Yes: $\mathrm{No}^{c}$ & $2: 10$ & $5: 5$ \\
\hline
\end{tabular}

Values given as mean \pm SD unless indicated differently. Statistical comparisons between the two groups were made using the Mann-Whitney U-test and a $p$-value $<0.05$ was considered significant

NS Not significant, Pack-years (number of cigarettes smoked per day/20) $\times$ number of years smoked, $F E V$, forced expiratory volume in $1 \mathrm{~s}, V C$ vital capacity

a At time of identification in the OLIN COPD study

b At time of inclusion in the current study

c At time of bronchoscopy in the current study 
Part 1

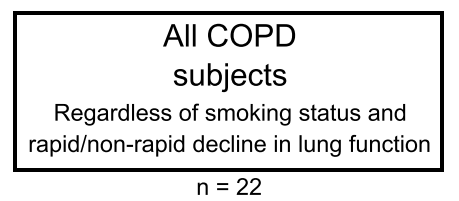

\section{subjects}

$\mathrm{n}=22$

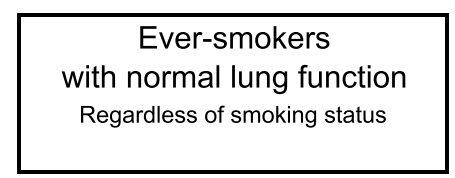

$\mathrm{n}=15$

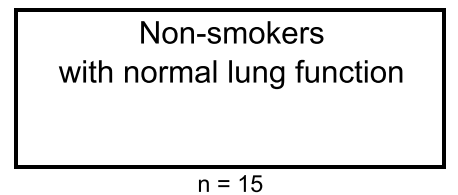

$n=15$

Hypothesis: Regulatory T cell populations and subpopulations would be affected by COPD status

\section{Part 2}

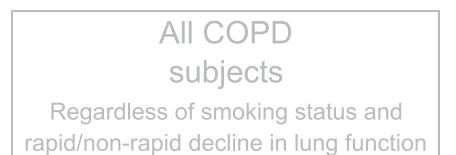

rapid/non-rapid decline in lung function
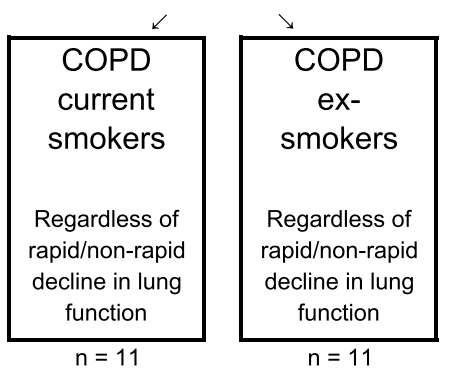

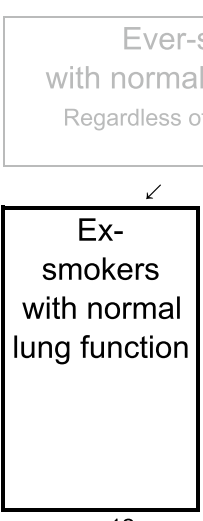

Ever-smokers

with normal lung function

Regardless of smoking status

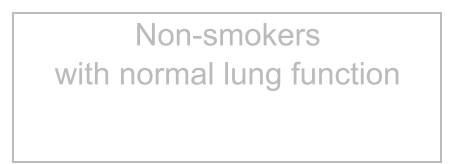

$\mathrm{n}=12$

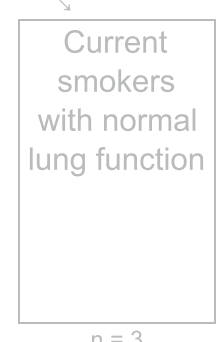

Hypothesis: Some of the differences found in part 1 would be associated with smoking, others with COPD status
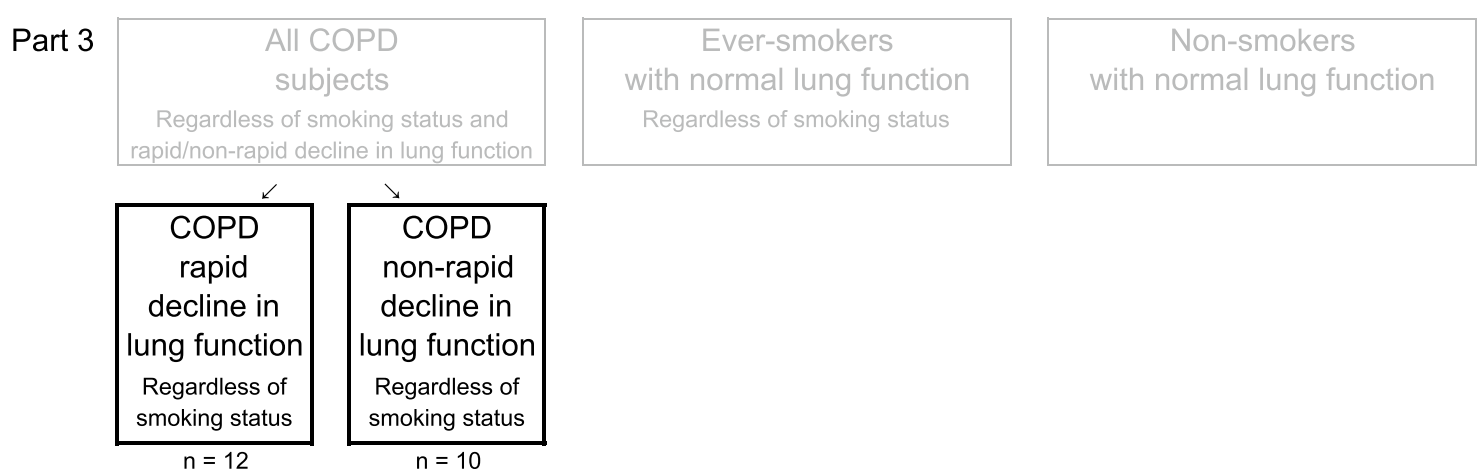

Hypothesis: Decreased expression of regulatory $T$ cells would be associated with a rapid decline in lung function

Fig. 1 Study design

non-smokers. It was hypothesized that COPD would be associated with decreased proportions of Tregs.

In part 2, it was hypothesized that some of the differences found in part 1 would be associated with current smoking and some with COPD. To separate between these, we compared (1) COPD current smokers to COPD ex-smokers; differences between these groups would likely be related to smoking status (since disease status is the same for both groups); and (2) COPD ex-smokers to ex-smokers with normal LF; differences between these groups would likely be related to disease status (since smoking status is the same for both groups).
In part 3, it was hypothesized that a rapid decline in LF would be associated with decreased proportions of Tregs. COPD rapid was compared to COPD non-rapid.

\section{Spirometry}

Following the American Thoracic Society/European Respiratory Society guidelines [12], dynamic spirometry variables were measured using a dry volume spirometer (Mijnhardt Vicatest 5, the Netherlands). If $\mathrm{FEV}_{1}$ was lower than $80 \%$ of predicted or if $\mathrm{FEV}_{1} / \mathrm{VC}$ was below 0.70 , reversibility testing was performed. The highest value out of pre- and post-bronchodilatation $\mathrm{FEV}_{1}$ and 
VC was reported. Swedish spirometric reference values were used [13].

\section{Bronchoscopy}

Bronchoscopies were performed at two locations (the Division of Respiratory Medicine and Allergy, Department of Medicine, Sunderby Central Hospital of Forgotten, Luleå, Sweden and the Division of Respiratory Medicine and Allergy, Department of Medicine, University Hospital, Umeå, Sweden) but by the same medical team. $30 \mathrm{~min}$ before the procedure, subjects were given $1.0 \mathrm{mg}$ of atropine subcutaneously. Some also received midazolam 4-8 $\mathrm{mg}$ per os. Local anaesthesia was achieved using lidocaine. All subjects were examined in the supine position. BAL was performed by infusing three aliquots of $60 \mathrm{ml}$ of sterile sodium chloride $(0.9 \%)$, $\mathrm{pH} 7.3$ at $37{ }^{\circ} \mathrm{C}$ in the middle lobe or lingula. The fluid was gently sucked back after each infusion and pooled into a tube placed in iced water. The recovered BAL fluid (BALF) was immediately transported to the laboratory for analysis. Bronchial wash $(2 \times 20 \mathrm{ml})$ and biopsies were also performed but not included in the analysis in the current study.

In three COPD subjects, BAL could not be performed due to problems tolerating the bronchoscopy procedure. In one COPD subject, BALF recovery was too low to perform flow cytometry analysis.

\section{Flow cytometry analysis}

BALF lymphocyte subsets were determined using a FACSCalibur $^{\mathrm{TM}}$ (Becton Dickinson) flow cytometer. BALF cells were centrifuged and adjusted to a final concentration of $10^{6}$ cells $/ \mathrm{ml}$. For each test, different fluorophoreconjugated antibody panels and subtype Ig conjugated with respective fluorophore were combined (Additional file 1: Table S1). Each test tube contained 200-400 $\mu \mathrm{l}$ of cell suspension $\left(10^{6}\right.$ cells $\left./ \mathrm{ml}\right)$ to which $10 \mu \mathrm{l}$ of each surface antibody was added and incubated for $30 \mathrm{~min}$ at $4{ }^{\circ} \mathrm{C}$ in darkness. After the surface marker staining, cells were washed twice with PBS and processed for intracellular staining of FoxP3 using eBioscience fixing and permeabilisation set (Thermo Fisher Scientific, Sweden). Briefly, cells were fixed and permeabilised with staining buffer at
$4{ }^{\circ} \mathrm{C}$ for $30 \mathrm{~min}$, thereafter washed twice by centrifugation at $4{ }^{\circ} \mathrm{C}$ for $10 \mathrm{~min}, 300 \mathrm{~g} .10 \mathrm{ml}$ FoxP3 antibody was added and allowed to bind for $30 \mathrm{~min}$ and thereafter cells were washed twice by adding permeabilisation buffer and centrifuging. Finally, PBS was added for performing analysis using FACSCalibur ${ }^{\mathrm{TM}}$ [8]. The lymphocyte population was confirmed by $\mathrm{CD} 45$ positive leucocyte population and gated based on the cells' physical characteristics in a region according to their characteristic forward scatter (FCS) and side scatter (SSC) profiles (Additional file 1: Figure S1). 6000-9000 cells were collected in $\mathrm{CD}^{+}$gate per test tube and percentage of CD3 subpopulation was counted out of gated lymphocytes and furthermore out of gated subpopulations (Table 2 and Additional file 1: Figure S1). Appropriate isotype-matched controls were used in all experiments. To ensure that autofluorescence did not influence the results, we stained for CD45/CD14 and compared that to the results of lymphocyte and macrophage gating. Flow cytometry data were acquired and analysed using Cell Quest Software (Becton Dickinson). Cell staining and data acquisition were performed at one centralized location.

\section{Statistical analysis}

Data was analysed using a two-step approach. In the first step, the investigated cell populations were analysed using group-wise comparisons with no outliers removed. For statistical comparisons between more than two groups, the Kruskal-Wallis test was used and a p-value $<0.05$ was considered significant. If the KruskalWallis test indicated significance, the Mann-Whitney U-test was carried out for post-hoc comparison between two groups.

In the second step, cell populations with significant between-group differences were further examined using multivariable mixed effects regression models with no outliers removed. These models were performed by specifying the response variable as the number of cells in the population evaluated (numerator) and the remaining number of lymphocytes (denominator) and incorporating subjects as random effect (random intercepts) in the linear predictor of a generalized linear model with a binomial error distribution. In the mixed effects

Table 2 Cell populations and FACS staining characteristics

\begin{tabular}{|c|c|c|}
\hline Population & Staining characteristics & $\begin{array}{l}\text { When given in percent, } \\
\text { calculated as proportion } \\
\text { of }\end{array}$ \\
\hline T cells & $\mathrm{CD} 3+$ & - \\
\hline Thelper cells & $\mathrm{CD}^{+} \mathrm{CD}^{+}$ & $\mathrm{CD}^{+}$ \\
\hline Activated T helper cells & $\mathrm{CD}^{+} \mathrm{CD}^{+}{ }^{+} \mathrm{CD} 25^{\text {bright }}$ & $\mathrm{CD}^{+} \mathrm{CD}^{+}$ \\
\hline $\mathrm{FoxP}^{+}$regulatory $\mathrm{T}$ cells & $\mathrm{CD}^{+} \mathrm{CD}^{+}{ }^{+} \mathrm{CD} 25^{\text {bright }} \mathrm{FoxP}^{+}$ & $\mathrm{CD}^{+} \mathrm{CD}^{+}{ }^{+} \mathrm{CD} 25^{\text {bright }}$ \\
\hline
\end{tabular}


regression models, adjustments were evaluated for age, sex, use of inhaled corticosteroids and smoking (where applicable). Smoking was evaluated both as a categorical variable (smoking status) and as a continuous variable (pack-years).

Correlation analyses were assessed with Spearman's ranked test.

Statistical analysis was performed using IBM SPSS Statistics (version 26) and, for calculating mixed effects regression models, statistical software package $\mathrm{R}$ (version 3.3.3; R Development Core Team, $\mathrm{R}$ foundation for Statistical Computing, Vienna, Austria).

\section{Results}

The study was analysed in three parts (Fig. 1), in part 1 and 2 the aim was the to distinguish the effect of COPD from that of smoking. Group-wise comparisons in these parts revealed no significant differences in Treg populations or in activated $\mathrm{T}$ helper cells (Additional file 1: Table S2).

In part 3 , the proportion of $\mathrm{FoxP}^{+}$regulatory $\mathrm{T}$ cells (FoxP3 ${ }^{+} / \mathrm{CD}^{+} \mathrm{CD}^{+} \mathrm{CD}^{\text {bright }}$ ) was significantly decreased in COPD rapid compared to COPD non-rapid (Fig. 2). The activated $\mathrm{T}$ helper cell population $\left(\mathrm{CD} 25^{\text {bright }} / \mathrm{CD}^{+} \mathrm{CD}^{+}\right)$did not differ significantly between groups (Fig. 2).
The multivariable mixed effects regression model showed a statistically significant relationship between decreased proportions of FoxP ${ }^{+}$regulatory $\mathrm{T}$ cells and having a rapid decline in LF (COPD rapid vs COPD nonrapid; OR (95\% CI) 0.38 (0.19-0.77); $\mathrm{p}=0.010)$. This relationship was significant also after adjusting for current smoking (OR (95\% CI) $0.36(0.18-0.72) ; \mathrm{p}=0.006)$ and inhaled corticosteroid (ICS) usage (OR $(95 \% \mathrm{CI}) 0.37$ (0.18-0.77); $\mathrm{p}=0.010$ ).

A moderate negative correlation was found between the proportion of FoxP3 ${ }^{+}$Tregs in BAL and annual decline in LF $(r=-0.57, p<0.05$; Fig. 3). No correlation was found between pack-years and Treg populations.

\section{Discussion}

\section{Part 1 and 2-Tregs and COPD}

Contrary to our hypothesis in part 1 (Fig. 1), no significant differences in Treg populations were found between COPD subjects and smokers or non-smokers with normal LF. Nor did part 2 reveal any alterations related to smoking or COPD status in these populations.

Previous studies have shown that in COPD, immune cell alterations in one compartment (e.g. peripheral blood) is not necessarily reflected in another (e.g. the lungs) [14]. The distribution of immune cells also differs between lung compartments (small/large airways,

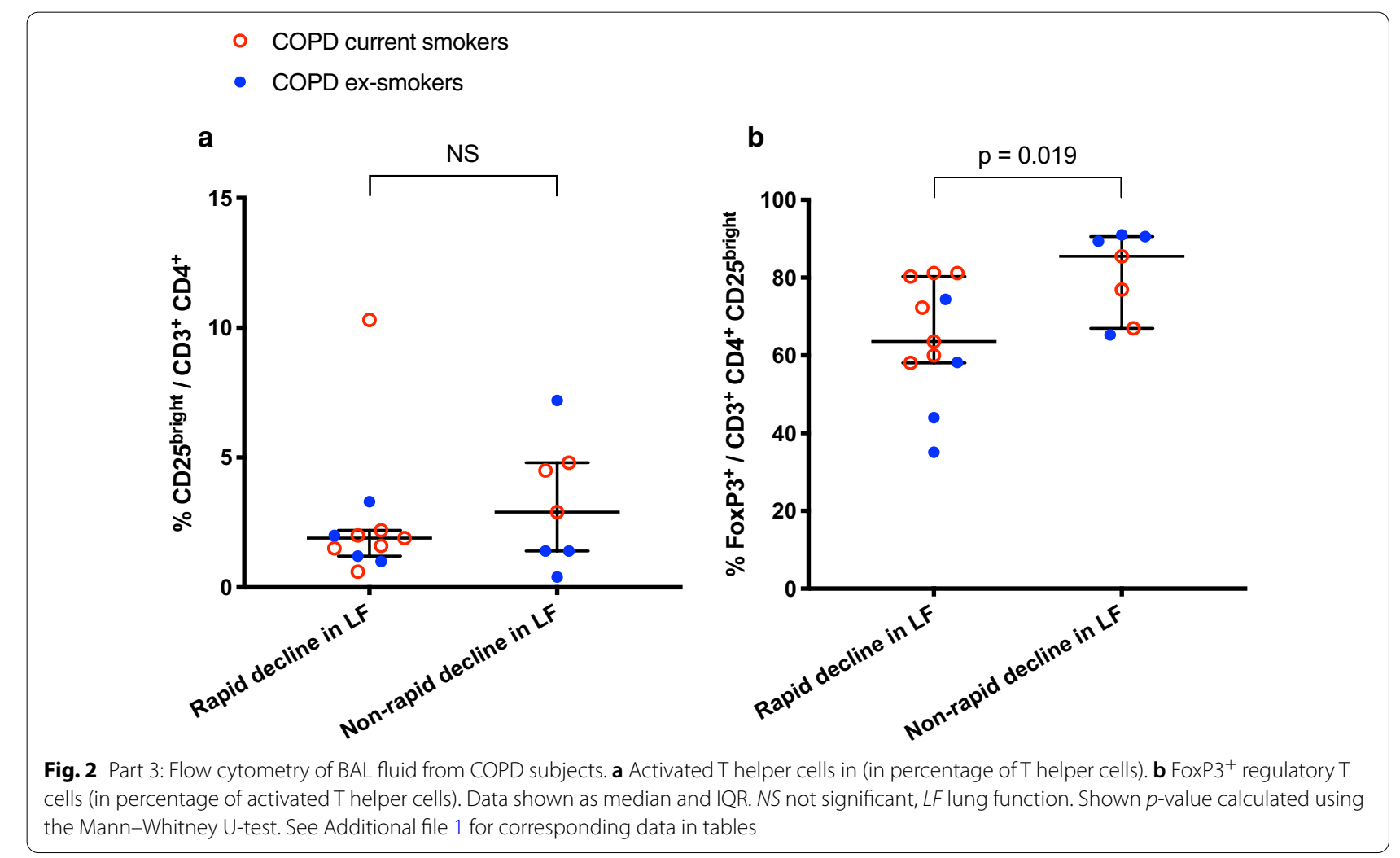




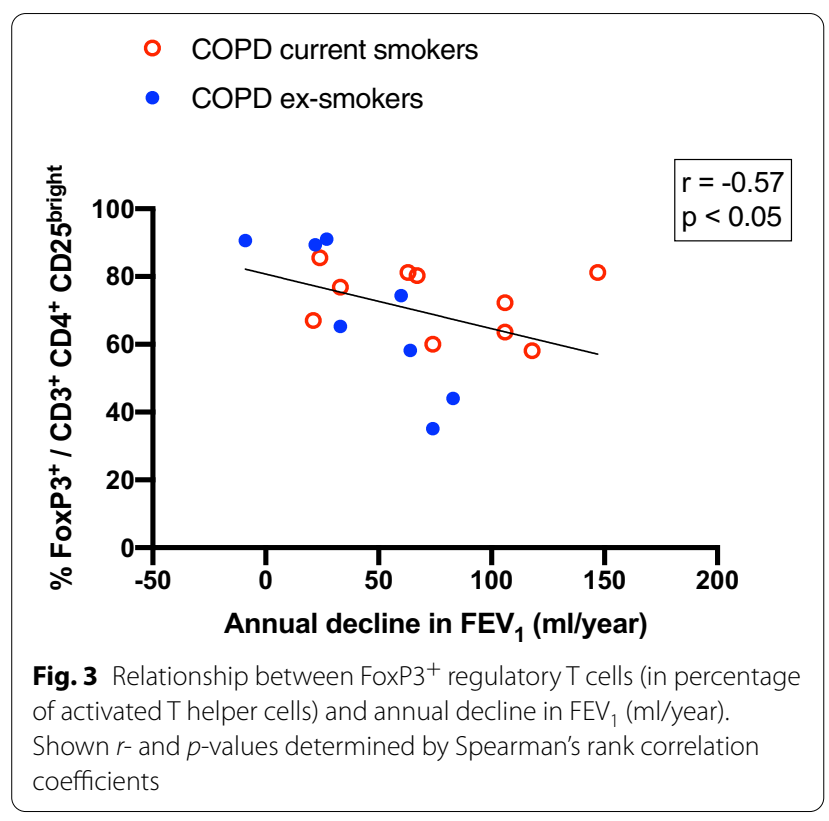

lymphoid tissue etc.) [15]. Thus, when evaluating the role of Tregs in COPD, results from studies of one compartment cannot with any certainty be applied to another. As for the bronchoalveolar compartment, there are not many previous studies of Tregs in BAL in relation to COPD.

Barcelo et al. found decreased levels of $\mathrm{CD} 4^{+} \mathrm{CD} 25^{\text {bright }}$ Tregs in BAL among COPD subjects compared to smokers with normal LF [1]. Smyth et al. found a correlation between pack-years and $\mathrm{CD} 4{ }^{+} \mathrm{CD} 25^{\text {bright }}$ Tregs in BAL [6]. Neither of these findings were confirmed in the current study.

One possible explanation is dissimilarities in the study populations. Both Smyth et al. and Barcelo et al. recruited their subjects from patients already known to the health care, while our subjects were recruited from the population-based OLIN studies [10]. Since only $20-30 \%$ of all individuals with COPD are identified by the health care $[16,17]$, using these different basis for recruitment would be expected to result in differences in study populations which in turn could affect results.

Another possible explanation could be that the current study is underpowered to detect these differences. As mentioned above, there few previous studies of Tregs and COPD in BAL, making power calculations uncertain.

\section{Part 3-Tregs and rapid decline}

To the best of our knowledge, this is the first study to investigate the role of Tregs in relation to the rapid decline phenotype of COPD. FoxP3 ${ }^{+}$Tregs were found to be significantly decreased in BAL from COPD subjects with a rapid decline in LF compared to COPD subjects with a non-rapid decline. The mixed effects regression analysis showed that this relationship was significant even after adjustments for smoking and use of ICS. Adjusting for the latter is important since ICS usage previously has been shown to lead to upregulation of FoxP3 ${ }^{+}$ Tregs [18-20].

Furthermore, a moderate negative correlation was found between $\mathrm{FoxP}^{+}$Tregs and annual decline in LF. This correlation must however be interpreted with caution given that COPD subjects with an annual decline in $\mathrm{LF}>30$ and $<60 \mathrm{ml} /$ year were by design not included in the study (as they were defined as not rapid nor nonrapid decliners).

While the hypothesis in part 3 of the study was confirmed and seemingly fits well with the proposed pathophysiological model-that decreased Tregs would lead to unregulated inflammation in response to tobacco smoke and to progression of the disease [1] - this study is cross-sectional and can as such not address the question of causality; if decreased Tregs do indeed lead to a rapid decline in LF or if it is the other way around.

In COPD in general, the decline in LF is thought to be the result of emphysema and airway remodelling. The development of emphysema has traditionally been described as due to infiltration of activated neutrophils leading to an imbalance in protease/antiprotease activity, but more recently additional factors such as oxidative stress and autoimmunity have also been proposed [21]. Remodelling of small airways is also thought to be related to infiltration of neutrophils as well as macrophages and lymphocytes, leading to epithelial thickening and smooth muscle hypertrophy. What these processes have in common is an abnormal inflammatory response to tobacco smoke.

Tregs have the ability to suppress over activated immune responses by contact-dependent mechanisms as well as through the release of cytokines-IL-10 (which has anti-inflammatory effects on neutrophils), IL-35 (which inhibits T-cell proliferation) and TGF- $\beta$ (which regulate epithelial cells, macrophages and fibroblasts) to name just a few [5].

It therefore seems plausible that an inability to upregulate Tregs could lead to a more rapid development of emphysema and small airway remodelling, and thus to a more rapid decline in LF. However, further longitudinal studies are needed to clarify the role of Tregs in relation to the rapid decline phenotype of COPD.

\section{Defining rapid decline}

As the interest for subtyping is growing within the field of COPD research, it is important to identify which of the proposed phenotypes are clinically relevant. Rapid 
decline has been described as a separate phenotype of COPD [14, 22] and one with a poor prognosis [23, 24].

There is however no established definition of the term 'rapid decline.' Many studies have used annual decline in $\mathrm{FEV}_{1}$ as the defining characteristic, but the cut-off between rapid and non-rapid decliners in these studies has varied between 40 and $90 \mathrm{ml} /$ year [24-27]. Other studies have opted for using percentiles instead of a fixed cut-off [28], percent of predicted $\mathrm{FEV}_{1}$ instead of in $\mathrm{FEV}_{1}$ [14] and using Hierarchical Bayesian Models [23] to identify rapid/non-rapid decliners.

To enable an evaluation of whether 'rapid decline' is indeed a relevant phenotype of COPD, it would be desirable to reach a consensus on the definition of the term. This should be addressed in further studies of COPD and the role of rate of decline in LF.

\section{Defining Tregs}

As mentioned in the background, there is a plethora of markers available for identifying the Treg population using flow cytometry. A high expression of FoxP3 is considered a hallmark of $\mathrm{CD}^{+}$Tregs [29], and was the defining characteristic used in the current study. In contrast to some previous studies, the $\mathrm{CD} 3^{+} \mathrm{CD} 4^{+} \mathrm{CD} 25^{\text {bright }}$ population was not defined as Tregs as it is likely to encompass activated T cells as well as regulatory ones [30].

Many previous studies of Tregs and COPD rely on blood samples for their analysis. One strength of the current study is that we instead have investigated the main target organ of COPD. Even though COPD is a systemic syndrome [21], when trying to uncover immunological mechanisms affecting the rate of decline in LF, investigating the lungs is likely to generate more relevant data than using peripheral blood.

Another strength is having recruited our subjects using longitudinal data from a well-characterized cohort and the use of a multivariable regression model. The former supplied reliable demographic and other data (i.e. on ICS usage, smoking habits) which then were used in the latter to make necessary adjustments. This enabled us to validate that significant between-group results were indeed associated with the major difference in characteristic and not with other confounding factors.

None of the subjects reported exacerbations in the four weeks leading up to the bronchoscopy. While exacerbations are important to consider in all studies of COPD, they might be of special importance when investigating Tregs as previous studies have shown that this cell population increases in patients with acute exacerbations [31].

One limitation of the current study is that women were underrepresented in the COPD rapid decline and nonsmokers groups (Table 1). Thus, we could not evaluate sex-specific differences, nor rule out that results were affected by these differences in group composition. There are previous studies indicating that the links between cellular events and phenotypes of COPD might be different in females compared to males [32]. Oestrogen has been proposed to have a protective role in the development of COPD [33], possibly through stimulating the expansion of Tregs [34].

Data on lymphocyte populations and subpopulations are presented in relative and not absolute cell numbers in the current study. The reason for this is that BAL recovery volumes, as in previous studies [35, 36], were found to be lower in COPD subjects compared to both non-smokers and ex-smokers with normal LF and also to vary within the COPD group [10]. We therefore believe that relative cell numbers better reflect differences in the inflammatory response.

\section{Conclusions}

No significant differences in airway regulatory T-cells were found between COPD subjects and smokers/nonsmokers with normal lung function. However, FoxP3 ${ }^{+}$ regulatory $\mathrm{T}$ cells were decreased in BAL from COPD subjects with a rapid decline in lung function compared to COPD subjects with a non-rapid decline. This result was significant before as well as after adjustments for ICS usage and smoking.

Based on previous research, it seems more plausible that a low expression of regulatory $\mathrm{T}$ cells would lead to a rapid decline in lung function, than the other way around. However, as the question of causality cannot be answered in a cross-sectional study such as the current, further longitudinal research is needed to clarify the relationship between regulatory $\mathrm{T}$ cells and the rapid decline phenotype of COPD.

\section{Supplementary information}

Supplementary information accompanies this paper at https://doi. org/10.1186/s12931-020-01593-9.

Additional file 1: Table S1. Antibodies conjugated fluorophores, clone and supplier. Figure S1. FACS gating strategy. Table S2. Flow cytometry analysis of activated and regulatory T cells in BAL fluid, given in percent. Table S3. Flow cytometry analysis of activated and regulatory $T$ cells in BAL fluid, given in cells $/ \mathrm{ml} \times 10^{2}$. Table S4. Differential cell counts of leukocytes of in BAL fluid, given in number of cells $/ \mathrm{ml} \times 10^{4}$.

\section{Abbreviations}

BAL: Bronchoalveolar lavage; BALF: Bronchoalveolar lavage fluid; Cl: Confidence interval; COPD non-rapid: COPD subjects with a non-rapid decline in lung function; COPDrapid: COPD subjects with a rapid decline in lung function; Ever-smokers: Current and ex-smokers with normal lung function; FACS: Fluorescence-activated cell sorting; $\mathrm{FEV}_{1}$ : Forced expiratory volume in one second; FoxP3: Forkhead Box P3; GOLD: Global Initiative for Obstructive Lung Disease; KOLIN: 'Respiratory and Cardiovascular Effects in COPD'; LF: Lung function; Non-smokers: Non-smokers with normal lung function; OLIN COPD study: Obstructive Lung Disease in Northern Sweden Chronic Obstructive 
Pulmonary Disease study; OR: Odds ratio; Tregs: Regulatory T cells; VC: Vital capacity.

\section{Acknowledgements}

The authors would like to thank Viktor Johansson Strandkvist, Helena Backman, Annika Johansson, Frida Holmström, Ove Björ, the OLIN studies and the Division of Respiratory Medicine and Allergy, Department of Medicine, Sunderby Central Hospital of Norrbotten, Luleå, Sweden for their contribution to the project.

\section{Authors' contributions}

Conception and design: JP, ABI, AL and AFB; bronchoscopies: RL, ABI and AFB; flow cytometry analysis: JP; interpretation: JP, ABI, ABu, AFB and JES; drafting of manuscript: JES. All authors read and approved the final manuscript.

\section{Funding}

Open Access funding provided by University Of Umea. Financial support was granted by the Swedish Heart-Lung foundation, the Västerbotten County Council, Visare Norr Fund/Northern County Councils Regional Federation, Umeå University, King Gustaf V's and Queen Victoria's Freemason Foundation, the Arnerska Research Foundation and the Kempe Foundation.

\section{Availability of data and materials}

The datasets used and/or analyzed during the current study are available from the corresponding author on reasonable request.

\section{Ethics approval and consent to participate}

Informed consent was obtained from all volunteers after verbal and written information and the study was approved by the local Ethics Committee at Umeå University, Sweden, and conducted in accordance with the declaration of Helsinki.

\section{Consent for publication}

Not applicable.

\section{Competing interests}

The authors declare that they have no competing interests.

\section{Author details}

${ }^{1}$ Department of Public Health and Clinical Medicine, Division of Medicine, Umeå University, 90187 Umeå, Sweden. ${ }^{2}$ Division of CBRN Defence and Security, Swedish Defence Research Agency, Stockholm, Sweden.

\section{Received: 22 April 2020 Accepted: 1 December 2020}

\section{Published online: 14 December 2020}

\section{References}

1. Barceló B, Pons J, Ferrer JM, Sauleda J, Fuster A, Agustí AGN. Phenotypic characterisation of T-lymphocytes in COPD: abnormal CD4+CD25+ regulatory T-lymphocyte response to tobacco smoking. Eur Respir J. 2008:31:555-62.

2. Hogg JC. Pathophysiology of airflow limitation in chronic obstructive pulmonary disease. Lancet. 2004;364:709-21.

3. Saetta M, Di Stefano A, Turato G, Facchini FM, Corbino L, Mapp CE, et al. CD8+ T-lymphocytes in peripheral airways of smokers with chronic obstructive pulmonary disease. Am J Respir Crit Care Med. 1998;157:822-6.

4. Eriksson Ström J, Pourazar J, Linder R, Blomberg A, Lindberg A, Bucht A, et al. Cytotoxic lymphocytes in COPD airways: increased NK cells associated with disease, iNKT and NKT-like cells with current smoking. Respir Res. 2018;19:244.

5. Lane N, Robins RA, Corne J, Fairclough L. Regulation in chronic obstructive pulmonary disease: the role of regulatory T-cells and Th17 cells. Clin Sci. 2010;119:75-86.

6. Smyth LC, Starkey C, Vestbo J, Singh D. CD4-regulatory cells in COPD patients. Chest. 2007;132:156-63.

7. Roos-Engstrand E, Ekstrand-Hammarström B, Pourazar J, Behndig AF, Bucht A, Blomberg A. Influence of smoking cessation on airway T lymphocyte subsets in COPD. J Chronic Obstr Pulm Dis. 2009;6:112-20.
8. Roos-Engstrand E, Pourazar J, Behndig AF, Bucht A, Blomberg A. Expansion of CD4+CD25+ helper $T$ cells without regulatory function in smoking and COPD. Respir Res. 2011;12:74.

9. Lindberg A, Lundbäck B. The obstructive lung disease in northern sweden chronic obstructive pulmonary disease study: design, the first year participation and mortality. Clin Respir J. 2008;2:64-71.

10. Lindberg A, Linder R, Backman H, Eriksson Ström J, Frølich A, Nilsson $U$, et al. From COPD epidemiology to studies of pathophysiological disease mechanisms: challenges with regard to study design and recruitment process: respiratory and cardiovascular effects in COPD (KOLIN). Eur Clin Respir J. 2017:4:1415095.

11. Vogelmeier CF, Criner GJ, Martinez FJ, Anzueto A, Barnes PJ, Bourbeau $J$, et al. Global strategy for the diagnosis, management, and prevention of chronic obstructive lung disease 2017 report. GOLD executive summary. Am J Respir Crit Care Med. 2017;2017:557-82.

12. Standardization of Spirometry. Update. American Thoracic Society. Am J Respir Crit Care Med. 1994;1995:1107-36.

13. Berglund E, Birath G, Bjure J, Grimby G, Kjellmer I, Sandqvist L, et al. Spirometric studies in normal subjects I. Acta Med Scand. 1963;173:185-92.

14. Higashimoto Y, Iwata T, Okada M, Satoh H, Fukuda K, Tohda Y. Serum biomarkers as predictors of lung function decline in chronic obstructive pulmonary disease. Respir Med. 2009;103:1231-8.

15. Sales DS, Ito JT, Zanchetta IA, Annoni R, Aun MV, Ferraz LFS, et al. Regulatory T-cell distribution within lung compartments in COPD. COPD. 2017;14:533-42.

16. Lamprecht B, Soriano JB, Studnicka M, Kaiser B, Vanfleteren LE, GnatiuC $L$, et al. Determinants of underdiagnosis of COPD in national and international surveys. Chest. 2015;148:971-85.

17. Danielsson P, Ólafsdóttir IS, Benediktsdóttir B, Gíslason T, Janson C. The prevalence of chronic obstructive pulmonary disease in Uppsala, Sweden - the Burden of Obstructive Lung Disease (BOLD) study: crosssectional population-based study. Clin Respir J. 2012;6:120-7.

18. Yang L, Ma Q-L, Yao W, Zhang Q, Chen H-P, Wang G-S, et al. Relationship between the anti-inflammatory properties of salmeterol/fluticasone and the expression of $\mathrm{CD} 4^{+} \mathrm{CD} 25^{+}$Foxp $3^{+}$ regulatory T cells in COPD. Respir Res. 2011;12:142-111. https://doi. org/10.1186/1465-9921-12-142.

19. Pace E, Di Sano C, La Grutta S, Ferraro M, Albeggiani G, Liotta G, et al. Multiple in vitro and in vivo regulatory effects of budesonide in CD4+ T lymphocyte subpopulations of allergic asthmatics. PLoS ONE. 2012;7:e48816.

20. Karagiannidis C, Akdis M, Holopainen P, Woolley NJ, Hense G, Rückert B, et al. Glucocorticoids upregulate FOXP3 expression and regulatory $T$ cells in asthma. J Allergy Clin Immunol. 2004;114:1425-33.

21. Agustí A, Hogg JC. Update on the pathogenesis of chronic obstructive pulmonary disease. N Engl J Med. 2019;381:1248-56.

22. Friedlander AL, Lynch D, Dyar LA, Bowler RP. Phenotypes of chronic obstructive pulmonary disease. J Chronic Obstr Pulm Dis. 2007;4:355-84.

23. Koskela J, Katajisto M, Kallio A, Kilpeläinen M, Lindqvist A, Laitinen T. Individual FEV 1trajectories can be identified from a COPD cohort. J Chronic Obstr Pulm Dis. 2016;13:425-30.

24. Larsson K. Aspects on pathophysiological mechanisms in COPD. J Intern Med. 2007:262:311-40.

25. Kim C, Park YB, Park SY, Park S, Kim C-H, Park SM, et al. COPD patients with exertional desaturation are at a higher risk of rapid decline in lung function. Yonsei Med J. 2014;55:732-8.

26. Devanarayan V, Scholand M-B, Hoidal J, Leppert MF, Crackower MA, O'Neill GP, et al. Identification of distinct plasma biomarker signatures in patients with rapid and slow declining forms of COPD. COPD. 2010;7:51-8.

27. Lindberg A, Larsson L-G, Rönmark E, Jonsson A-C, Larsson K, Lundbäck B. Decline in FEV1 in relation to incident chronic obstructive pulmonary disease in a cohort with respiratory symptoms. J Chronic Obstr Pulm Dis. 2007:4:5-13.

28. Nishimura M, Makita H, Nagai K, Konno S, Nasuhara Y, Hasegawa M, et al. Annual change in pulmonary function and clinical phenotype in chronic obstructive pulmonary disease. Am J Respir Crit Care Med. 2012;185:44-52.

29. Chiappori A, Folli C, Balbi F, Caci E, Riccio AM, De Ferrari L, et al. CD4(+) CD25(high)CD127(-) regulatory T-cells in COPD: smoke and drugs effect. World Allergy Organ J. 2016;9:5. 
30. Plumb J, Smyth LJC, Adams HR, Vestbo J, Bentley A, Singh SD. Increased T-regulatory cells within lymphocyte follicles in moderate COPD. Eur Respir J. 2009;34:89-94.

31. Dancer R, Sansom DM. Regulatory T cells and COPD. Thorax. 2013:68:1176-8

32. Forsslund H, Yang M, Mikko M, Karimi R, Nyrén S, Engvall B, et al. Gender differences in the T-cell profiles of the airways in COPD patients associated with clinical phenotypes. COPD. 2017;12:35-48.

33. Ohar J, Fromer L, Donohue JF. Reconsidering sex-based stereotypes of COPD. Prim Care Respir J. 2011;20:370-8.

34. Tai $P$, Wang J, Jin $\mathrm{H}$, Song $X$, Yan J, Kang Y, et al. Induction of regulatory $T$ cells by physiological level estrogen. J Cell Physiol. 2008;214:456-64
35. Forsslund H, Mikko M, Karimi R, Grunewald J, Wheelock ÅM, Wahlström $J$, et al. Distribution of T-cell subsets in BAL fluid of patients with mild to moderate COPD depends on current smoking status and not airway obstruction. Chest. 2014;145:711-22.

36. Löfdahl JM, Cederlund K, Nathell L, Eklund A, Sköld CM. Bronchoalveolar lavage in COPD: fluid recovery correlates with the degree of emphysema. Eur Respir J. 2005;25:275-81.

\section{Publisher's Note}

Springer Nature remains neutral with regard to jurisdictional claims in published maps and institutional affiliations.
Ready to submit your research? Choose BMC and benefit from:

- fast, convenient online submission

- thorough peer review by experienced researchers in your field

- rapid publication on acceptance

- support for research data, including large and complex data types

- gold Open Access which fosters wider collaboration and increased citations

- maximum visibility for your research: over $100 \mathrm{M}$ website views per year

At BMC, research is always in progress.

Learn more biomedcentral.com/submissions 